\title{
Effect of cooking with interesterified margarine in the chemical composition of fish
}

\author{
Bruna Mergulhão de BRITO ${ }^{1 *}$, Giselda Macena LIRA ${ }^{1}$ (D), Ariane Gleyse Azevedo PINHEIRO1, \\ Cláudia Maria Alexandre da Silva SANTANA ${ }^{1}$, Isabela Luna AMARAL ${ }^{1}$
}

\begin{abstract}
With the objective of evaluating the influence of the heat treatment on the chemical composition of fish refried with interesterified margarine, the white hake (Cynoscion leiarchus), fresh and braised forms, was determined its centesimal composition, calorific value and fatty acid profile. Cooking with interesterified margarine resulted in a reduction of $12 \%$ in protein content and $7.5 \%$ in ash content. The lipid content increased after frying (112\%). As well as total saturated fatty acids (82.8\%), monounsaturated fatty acids (858\%) and polyunsaturated fatty acids (567\%). There was a 33\% reduction in total arachidonic and $48 \%$ in total DHA, in the braised hake with interesterified margarine in relation to fresh hake.
\end{abstract}

Keywords: Cynoscion leiarchus; centesimal composition; fatty acids.

Practical Application: As the consumption of fish is related to numerous health benefits due to its chemical composition, this study has an importance in obtaining information for the thermal processing of this food. the changes in chemical composition suffered by white hake after being braided with interesterified margarine proved to be favorable to consumption.

\section{Introduction}

Several studies have reported the importance of lipids present in fish because they are a source of long chain polyunsaturated fatty acids. The fatty acids of the omega- 3 series, such as eicosapentaenoic (EPA) and docosahexaenoic (DHA), have received greater attention because they are related to the minimization of inflammatory processes (Barbalho et al., 2011), reduction of risk of disease development (Santos \& Bortolozo, 2008), asthma, hypertension, lupus, skin and eye diseases, depression (Guiné \& Henriques, 2011) and Alzheimer's disease (Domínguez, 2008).

The chemical composition of the fish and their nutritional value are well related to several factors such as their original habitat, their diet, season, among others (Piñeiro-Corrales et al., 2013). However, an important factor is the heat treatment, as it can cause chemical changes in the lipid profile of the food and thus modify its nutritional value. In this case, the temperature intensity, the process duration, as well as the form of heat transfer and the cooking medium used influence these changes (Rosa et al., 2006).

In the process of cooking a source of fat and the internal water of the food is used as means of heat transmission. This cooking technique stands out for emphasizing the sensorial qualities and minimizing the nutritional losses, besides being a fast process (Sucupira et al., 2012). Margarine and vegetable oils are widely used as a cooking medium for sautéing, seasoning foods and improving their flavor (Amorim et al., 2010).

After studies of the nutritional damage caused by trans fat consumption, the food industry has sought to replace hydrogenated margarine with interesterified margarine, which has equivalent functionality, economic viability and a similar saturated fatty acid content. (Neeharika et al., 2015).
White hake (Cynoscion leiarchus) is a marine fish, widely distributed along the Brazilian Northeast coast, and much appreciated by the population (Oliveira et al., 2014). However, there is no data in the scientific literature regarding the effects of cooking preparations on their composition. Therefore, the objective of this study was to verify the alterations in fatty acid profile and centesimal composition in braised white hake (Cynoscion leiarchus) with interesterified margarine.

\section{Materials and methods}

\subsection{Samples}

Ten samples of white hake (Cynoscion leiarchus) from the sea coast of Maceió-Alagoas-Brazil, between the geographical coordinates $8^{\circ} 8^{\prime} 12$ " $\mathrm{S}$ and $10^{\circ} 29^{\prime} 12$ “'S, where the water reaches a temperature higher than $20^{\circ} \mathrm{C}$, and presented high and constant salinity, were purchased between April and August 2014. Each sample consisted of $900 \mathrm{~g}$ of fish, which were packed in plastic bags, kept on ice and immediately transported to the laboratory. The filet was separated into three groups of $300 \mathrm{~g}$. Group 1 composed the raw samples and group 2 , the samples braised with interesterified margarine. The white hake steaks were sautéed with $15 \mathrm{~g}$ of interesterified margarine for 12 minutes at $81.5^{\circ} \mathrm{C}$.

After the heat treatment, the steaks were placed in an absorbent paper to remove excess oil. Samples were crushed, weighed, identified and frozen at $-17^{\circ} \mathrm{C}$ until the analyzes were performed, starting the following day. The fatty acid profile of 3 samples of interesterified margarine purchased from a supermarket was also analyzed. 


\subsection{Centesimal composition and Total Caloric Value (TCV)}

The homogenized muscle tissue was immediately analyzed in duplicate for moisture content $\left(105^{\circ} \mathrm{C}\right)$, fixed mineral residue (ash) by incineration in muffle at $550{ }^{\circ} \mathrm{C}$ and total protein content by Kjeldahl method (Association of Official Analytical Chemists, 1990). Total lipids were cold extracted by the method of Folch et al. (1957), total lipid quantification was performed gravimetrically and the remaining lipid fraction conditioned at $-20{ }^{\circ} \mathrm{C}$ in an amber flask under nitrogen atmosphere for further analysis. Carbohydrates were quantified by difference, by subtracting percentages of moisture, ashes, proteins and lipids from the total percentage of nutrients. The results were expressed as a percentage.

The total caloric value was calculated from the corresponding caloric coefficients for proteins, lipids and carbohydrates, respectively 4, 9 and $4 \mathrm{kcal} / \mathrm{g}$ (Watt \& Merrill, 1963).

\subsection{Profile of fatty acids}

Lipids, obtained according to Folch et al. (1957), were converted to methyl esters (Hartman \& Lago, 1973) and injected into a gas phase (GC) chromatograph. The Agilent Technologies brand GC, model 7890A with model CP-Sil 88 column, $100 \mathrm{~m}$, $0.25 \mathrm{~mm}$ d.i, $0.20 \mu \mathrm{m}$ film. Furnace with temperature of $140^{\circ} \mathrm{C} / 2$ min - heating from $140{ }^{\circ} \mathrm{C}$ to $230^{\circ} \mathrm{C}\left(4.5^{\circ} \mathrm{C} / \mathrm{min}\right)$, remaining at $230{ }^{\circ} \mathrm{C}$ for 28 minutes. Split type injector, split ratio: 1:75, temperature: $260{ }^{\circ} \mathrm{C}$, flow: $0.6 \mathrm{~mL} / \mathrm{min}$ and constant pressure. Make up temperature of $260^{\circ} \mathrm{C}$, Make up (Nitrogen): $30 \mathrm{~mL} / \mathrm{min}$, hydrogen: $30 \mathrm{~mL} / \mathrm{min}$ and synthetic air: $300 \mathrm{~mL} / \mathrm{min}$. Standard fatty acid methyl esters were used, comparing the retention time of the methyl esters of the samples and the standards. The quantification of the fatty acids was done by normalization of area, expressing the result in $\mathrm{mg} / 100 \mathrm{~g}$.

\subsection{Nutritional Quality Indexes (NQI) of lipids}

The nutritional quality of the lipid fraction was evaluated by three indices from the composition data in fatty acids, according to the following calculations:

Atherogenicity Index $(\mathrm{AI})=[(\mathrm{C} 12: 0+(4 \mathrm{x} C 14: 0)+\mathrm{C} 16: 0)] /$ $\left(\sum \mathrm{MUFA}+\sum \mathrm{n} 6+\sum \mathrm{n} 3\right)$

Thrombogenicity Index $(\mathrm{TI})=(\mathrm{C} 14: 0+\mathrm{C} 16: 0+\mathrm{C} 18: 0) /$ $\left[\left(0.5 \times \sum\right.\right.$ AGMI $)+\left(0.5 \times \sum \mathrm{n} 6+\left(3 \times \sum \mathrm{n} 3\right)+\left(\sum \mathrm{n} 3 / \sum \mathrm{n} 6\right)\right]$ both according to Ulbricht \& Southgate (1991) where: MUFA = all monounsaturated acids.

Hypocholesterolemic and hypercholesterolemic fatty acids $(\mathrm{H} / \mathrm{H})=(\mathrm{C} 18: 1$ cis9 $+\mathrm{C} 18: 2 \mathrm{n} 6+\mathrm{C} 20: 4 \mathrm{n} 6+\mathrm{C} 18: 3 \mathrm{n} 3+\mathrm{C} 20:$ $5 n 3+\mathrm{C} 22: 5 n 3+\mathrm{C} 22: 6 n 3) /(\mathrm{C} 14: 0+\mathrm{C} 16: 0)$, according to Santos-Silva et al. (2002).

\subsection{Statistical analysis}

The experiment was conducted in a completely randomized design with three treatments. The data were submitted to analysis of variance with the significance being evaluated through the F test, considering the significance level 5\%. The analyzes were performed using the SAEG - System for Statistical Analysis, version 9.1 (2007).

\section{Results and discussion}

\subsection{Centesimal composition and caloric value}

The results of the centesimal composition and caloric value of the in natura and braised white hake are shown in Table 1.

The process of cooking with interesterified margarine resulted in a significant reduction $(\mathrm{p}<0.05)$ in the moisture content of the raw material in natura. Ferreira et al. (2007) also reported a reduction in moisture content in fillets of Nile Tilapia (Oreochromis niloticus) after cooking in water (76.73\%), frying in soybean oil (66.56\%), roasting in an electric oven $(74.56 \%)$ and roasted in a microwave oven $(68.07 \%)$, compared to fresh (79.39\%).

Fresh hake represents a source of proteins of high biological value. After the interesterified margarine cooking process, white hake protein, ash and carbohydrate percentages increased significantly $(\mathrm{p}<0.05)$ compared to fresh fish. This increase is due to the concentration of these nutrients after the reduction of the moisture content (Rosa et al., 2006).

Tonial et al. (2010) reported a lower protein content in grilled Salmon, with no added oils or fats $(22.71 \%)$, when compared to the braised hake with interesterified margarine $(29.68 \%)$. Considering that the protein content of these in natura fish was similar to that of white hake (fresh: 19.95\%), it was observed that the safflower method had the advantage of lower protein loss, with a higher concentration of this nutrient.

Raw white hake can be considered, according to Ackman (1989), as a low-fat food (up to 4\%). The increase in the lipid content detected in hake with interesterified margarine is due to the incorporation of the cooking media used in the preparation of the food. The interesterified margarine label used in this study indicates $80 \%$ total fat.

In order to verify the effect of the heat treatment, the results were calculated on the dry basis to eliminate the influence of moisture (Table 2). Protein, lipid and ash contents of the braised hake with interesterified margarine had a significant difference $(\mathrm{p}<0.05)$, in relation to fresh hake. The cooking process with interesterified margarine resulted in a reduction of $12 \%$ in protein content and $7.5 \%$ in ash content when compared to fresh

Table 1. Centesimal composition $(\mathrm{g} / 100 \mathrm{~g})$ and caloric value $(\mathrm{kcal} / 100 \mathrm{~g})$ of white fresh hake and braised with interesterified margarine, on a wet basis.

\begin{tabular}{lllcccc}
\hline \multirow{2}{*}{ White hake } & \multicolumn{5}{c}{ Centesimal composition } \\
\cline { 2 - 7 } & Moisture & Protein & Lipids & Carbohydrates & Ashes & Calories $(\mathrm{kcal} / 100 \mathrm{~g})$ \\
\hline Fresh & $77.59^{\mathrm{A}}( \pm 0.28)$ & $19.85^{\mathrm{A}}( \pm 0.38)$ & $1.47^{\mathrm{A}}( \pm 0.23)$ & $0.04^{\mathrm{A}}( \pm 0.02)$ & $1.07^{\mathrm{A}}( \pm 0.07)$ & $92.79^{\mathrm{A}}( \pm 1.9)$ \\
Braised & $62.34^{\mathrm{B}}( \pm 0.4)$ & $29.68^{\mathrm{B}}( \pm 0.97)$ & $5.67^{\mathrm{B}}( \pm 0.55)$ & $0.46^{\mathrm{B}}( \pm 0.47)$ & $1.85^{\mathrm{B}}( \pm 0.12)$ & $174.4^{\mathrm{B}}( \pm 1.61)$ \\
\hline
\end{tabular}

Mean of samples analyzed in duplicate. In the same column, averages of the same base followed by the same letter in the row do not differ from each other by the $\mathrm{F}$ test at the $5 \%$ level of significance. 
Table 2. Centesimal composition $(\mathrm{g} / 100 \mathrm{~g})$ of fresh white hake and braised with interesterified margarine, on a dry basis.

\begin{tabular}{cccc}
\hline \multirow{2}{*}{ White Wake } & \multicolumn{3}{c}{ Centesimal composition } \\
\cline { 2 - 4 } & Protein & Lipids & Ashes \\
\hline Fresh & $88.92^{\mathrm{a}}( \pm 2.01)$ & $6.85^{\mathrm{a}}( \pm 0.84)$ & $4.31^{\mathrm{a}}( \pm 0.32)$ \\
Braised & $78.94^{\mathrm{b}}( \pm 2.47)$ & $16.7^{\mathrm{b}}( \pm 1.07)$ & $4.91^{\mathrm{b}}( \pm 0.31)$ \\
\hline
\end{tabular}

Mean of samples analyzed in duplicate. Mean obtained by calculation [( $\left.\left.\mathrm{x}^{*} 100 / 100-\mathrm{sm}\right)\right]$, where $\mathrm{x}=$ sample component value on wet basis and $\mathrm{sm}=$ sample moisture. In the same column, averages of the same base, followed by the same letter in the row do not differ by the $\mathrm{F}$ test at the $5 \%$ level of significance.

fish. These reductions can be explained due to losses of these nutrients to the cooking medium (Rosa et al., 2006). The lipid content increased significantly $(\mathrm{p}<0.05)$ after steaming with margarine (16.7\%) due to incorporation of the cooking media.

\subsection{Profile in fatty acids}

Table 3 presents the profile of fatty acids found in fresh fish and braised with interesterified margarine as well as the total sum of saturated, monounsaturated and polyunsaturated fatty acids.

The most prevalent fatty acids in fresh white hake were: C16: 0, C18: 1n-9c, C16: 1n-7, C22: 6n-3 and C18: 0. Of these, only saturated palmitic fatty acid is considered to be harmful to health. The most prevalent for the braised fish with interesterified margarine were: C18: 2n-6, C18: 1n-9, C16: 0, and C:18.

The predominant saturated fatty acids were palmitic, stearic and lauric, with significant elevations ( $\mathrm{p}<0.05$ ), about 2,4 and 16 times, respectively, in relation to the in samples fresh.

These saturated fatty acids were detected in high amounts in the interesterified margarine (Table 4), evidencing that there was incorporation of the cooking medium in the fish. The fatty acid profile found in the interesterified margarine is shown in Table 4. The analysis showed that the fatty acid C18: $2 \mathrm{n}-6$, followed by C18: 1n-9, C16: 0, C18: 0, C18: 3n-3, C12: 0 and C14: 0, were the most abundant in this cooking medium.

Although saturated fatty acids have an influence on the increase in the plasma concentration of cholesterol and LDL, stearic acid does not raise cholesterolemia, because the dehydrogenation of this acid is faster than the chain elongation, making it more rapidly converted to oleic acid in the liver, by means of desaturases (Micha \& Mozaffarian, 2010).

According to Santos et al. (2012), the consumption of $1 \%$ of the total caloric value (VCT) of saturated acids is associated with an increase of 1.3 to $1.7 \mathrm{mg} / \mathrm{dL}$ in LDL-c and 0.4 to $0.5 \mathrm{mg} / \mathrm{dL}$ of lipoprotein of high density (HDL-c), the reverse occurring when saturated fat intake is reduced.

After cooking with interesterified margarine, the concentration of oleic monounsaturated fatty acid increased significantly $(\mathrm{p}<0.05)$, by about 4 times, when compared to the values of fresh white hake, as it is found in high amounts in used, causing its incorporation. However, there was no significant difference $(p>0.05)$ between the braised and fresh.

On the contrary, other studies demonstrate losses of the oleic fatty acid after the heat treatment. Gladyshev et al. (2007)
Table 3. Fatty acids $(\mathrm{mg} / 100 \mathrm{~g})$ of fresh white hake, braised in interesterified margarine.

\begin{tabular}{|c|c|c|}
\hline FATTY ACIDS & Fresh & Braised \\
\hline \multicolumn{3}{|l|}{ SATURATED } \\
\hline Lauric (C12:0) & $9.56( \pm 7.92) \mathrm{a}$ & $156.74( \pm 21.61) \mathrm{b}$ \\
\hline Myristic (C14:0) & $44.44( \pm 11.23) \mathrm{b}$ & $105.09( \pm 5.58) \mathrm{a}$ \\
\hline Pentadecanoic (C15:0) & $11.42( \pm 1.65) \mathrm{a}$ & $14.29( \pm 1.13) \mathrm{a}$ \\
\hline Palmític (C16:0) & $457.98( \pm 57.9) \mathrm{a}$ & $987.39( \pm 86.1) \mathrm{b}$ \\
\hline Heptadecanoic (C17:0) & $12.49( \pm 2.06) \mathrm{a}$ & $18.08( \pm 2.2) \mathrm{a}$ \\
\hline Stearic $(\mathrm{C} 18: 0)$ & $120.82( \pm 12.03) \mathrm{a}$ & $469.43( \pm 45.2) \mathrm{b}$ \\
\hline Arachidic (C20:0) & $5.50( \pm 2.56) \mathrm{a}$ & $20.09( \pm 3.07) \mathrm{b}$ \\
\hline Henicosanoic (C21:0) & $1.56( \pm 0.82) \mathrm{a}$ & $0.96( \pm 0.13) \mathrm{a}$ \\
\hline Behenic (C22:0) & $4.2( \pm 2.97) \mathrm{a}$ & $16.29( \pm 2.36) \mathrm{b}$ \\
\hline Tricosanoic (C23:0) & $0.32( \pm 0.45) \mathrm{a}$ & $0( \pm 0) \mathrm{a}$ \\
\hline Lignoceric (C24:0) & $0.94( \pm 0.98) \mathrm{a}$ & $5.6( \pm 1.82) \mathrm{b}$ \\
\hline \multicolumn{3}{|l|}{ MONOUNSATURATED } \\
\hline Myristoleic (C14:1n-5) & $1.33( \pm 0.91) \mathrm{a}$ & $1.03( \pm 0.22) \mathrm{a}$ \\
\hline Palmitoleic (C16:1n-7) & $202.88( \pm 24.89) \mathrm{a}$ & $262.26( \pm 8.2) \mathrm{a}$ \\
\hline Heptadecenoic (C17:1) & $10.16( \pm 1.86) \mathrm{a}$ & $12.96( \pm 0.55) \mathrm{a}$ \\
\hline Oleic (C18:1n-9) & $316.97( \pm 32.38) \mathrm{a}$ & $1274.44( \pm 80.09) \mathrm{b}$ \\
\hline Cetoleic (C20:1n-11) & $19.6( \pm 3.59) \mathrm{ab}$ & $30.47( \pm 2.49) \mathrm{a}$ \\
\hline Docosenoic (C22:1) & $2.77( \pm 1.67) \mathrm{a}$ & $3.41( \pm 0.58) \mathrm{a}$ \\
\hline Nervonic (C24:1) & $4.68( \pm 2.59) \mathrm{a}$ & $6.91( \pm 0.62) \mathrm{a}$ \\
\hline \multicolumn{3}{|l|}{ POLYUNSATURATED } \\
\hline Linoleic (C18:2n-6) & $16.57( \pm 2.9) \mathrm{a}$ & $1707.4( \pm 110.81) \mathrm{b}$ \\
\hline Linolenic (C18:3n-3) & $15.67( \pm 3.66) \mathrm{a}$ & $169.99( \pm 12.86) \mathrm{b}$ \\
\hline Eicosadienoic (C20:2n-6) & $5.58( \pm 2.74) \mathrm{a}$ & $7.99( \pm 0.48) \mathrm{a}$ \\
\hline Di-homo- $\gamma$-linolenic (C20:3n-6) & $1.46( \pm 0.34) \mathrm{a}$ & $0( \pm 0) \mathrm{a}$ \\
\hline Eicosatrienoic (C20:3n-3) & $2.24( \pm 1.45) \mathrm{a}$ & $1.18( \pm 0.01) \mathrm{a}$ \\
\hline Arachidonic (C20:4n-6) & $56.16( \pm 8.1) \mathrm{a}$ & $71.51( \pm 4.94) \mathrm{a}$ \\
\hline Docosadienoic (C22:2n-6) & $0.35( \pm 0.49) \mathrm{a}$ & $0( \pm 0) \mathrm{a}$ \\
\hline Eicosapentaenoic (EPA) (C20:5n-3) & $61.36( \pm 10.28) \mathrm{a}$ & $78.25( \pm 12.67) \mathrm{ab}$ \\
\hline Docosapentaenoic (C22:5n-3) & $43.36( \pm 12.47) \mathrm{a}$ & $55.93( \pm 5.09) \mathrm{a}$ \\
\hline Docosahexaenoic (DHA) (C22:6n3) & $152.56( \pm 33.72) \mathrm{a}$ & $155.66( \pm 12.61) \mathrm{a}$ \\
\hline \multicolumn{3}{|l|}{ TRANS } \\
\hline Elaidic (C18:1n-9t) & $4.61( \pm 1.55) \mathrm{a}$ & $4.69( \pm 0.83) \mathrm{a}$ \\
\hline Linolelaidic (C18:2n-6t) & $3.94( \pm 0.76) \mathrm{a}$ & $19.15( \pm 0.65) \mathrm{b}$ \\
\hline Linolenelaidic (C18:3n-3t) & $18.26( \pm 6.26) \mathrm{a}$ & $43.33( \pm 2.73) \mathrm{b}$ \\
\hline$\Sigma$ Saturated & $669.25( \pm 9.32) \mathrm{a}$ & $1794( \pm 15.4) \mathrm{b}$ \\
\hline ¿Monounsaturated & $558.4( \pm 8.68) \mathrm{a}$ & $1591.5( \pm 13.25) \mathrm{b}$ \\
\hline ¿Polyunsaturated & $355.34( \pm 6.93) \mathrm{a}$ & $2247.9( \pm 15.19) \mathrm{b}$ \\
\hline$\sum$ Trans & $26.82( \pm 2.86) \mathrm{a}$ & $67.19( \pm 1.4) \mathrm{a}$ \\
\hline Polyunsaturated / Saturated & $0.53 \mathrm{a}$ & $1.25 \mathrm{~b}$ \\
\hline$\sum \mathrm{n}-3$ & $275.2( \pm 12.31) \mathrm{a}$ & $461.01( \pm 7.14) \mathrm{b}$ \\
\hline$\sum n-6$ & $80.14( \pm 2.91) \mathrm{a}$ & $1786.9( \pm 23.24) \mathrm{b}$ \\
\hline Relation $n-6 / n-3$ & $1: 3.43 a$ & $3.87: 1 b$ \\
\hline $\mathrm{EPA}+\mathrm{DHA}$ & $213.93( \pm 22.00) \mathrm{a}$ & $270.62( \pm 8.89) \mathrm{a}$ \\
\hline Unidentified & $150.7( \pm 46.7) \mathrm{a}$ & $233.91( \pm 215.18) \mathrm{b}$ \\
\hline
\end{tabular}

Mean of 10 samples analyzed in duplicate, with standard deviation between parentheses. In the same line, means of the same base followed by the same letter in the line do not differ from each other by the $\mathrm{F}$ test at the $5 \%$ level of significance.

also reported reduced concentration of this fatty acid in trout (Salmo trutta) fried with sunflower oil.

According to Oliveira et al. (2012), prospective studies of secondary prevention show that doses of 500 to $1800 \mathrm{mg}$ of EPA + DHA, from supplements or fish consumption, reduce mortality 
Table 4. Fatty acids $(\mathrm{mg} / 100 \mathrm{~g})$ of interesterified margarine in Brazil, used in the study.

\begin{tabular}{|c|c|}
\hline FATTY ACIDS & $\begin{array}{c}\text { INTERESTERIFIED } \\
\text { MARGARINE }\end{array}$ \\
\hline \multicolumn{2}{|l|}{ SATURATED } \\
\hline Caprylic acid (C 8:0) & $50.97( \pm 11.09)$ \\
\hline Capric acid (C 10:0) & $184.65( \pm 38.99)$ \\
\hline Lauric (C12:0) & $2702.17( \pm 180.87)$ \\
\hline Mystical (C14:0) & $1033.80( \pm 11.14)$ \\
\hline Palmitic (C16:0) & $10051.96( \pm 44.39)$ \\
\hline Heptadecanoic (C17:0) & $72.72( \pm 2.77)$ \\
\hline Stearic (C18:0) & $7050.88( \pm 25.08)$ \\
\hline Arachidic (C20:0) & $277.16( \pm 2.78)$ \\
\hline Behenic (C22:0) & $279.11( \pm 5.57)$ \\
\hline Lignoceric (C24:0) & $77.00( \pm 35.65)$ \\
\hline \multicolumn{2}{|l|}{ MONOUNSATURATED } \\
\hline Palmitoleic (C16:1n-7) & $84.51( \pm 2.78)$ \\
\hline Oleic (C18:1n-9) & $18302.62( \pm 119.58)$ \\
\hline Cetoleic (20:1n-11) & $131.71( \pm 2.78)$ \\
\hline \multicolumn{2}{|l|}{ POLYUNSATURATED } \\
\hline Linoleic (C18:2n-6) & $33381.5( \pm 133.68)$ \\
\hline Gamma-linolenic acid (C18:3n-6) & $23.64( \pm 0)$ \\
\hline Linolenic (C18:3n-3) & $2789.34( \pm 19.45)$ \\
\hline Eicosapentaenoic (C20:5n-3) & - \\
\hline \multicolumn{2}{|l|}{ TRANS } \\
\hline Elaidic (C18:1n-9t) & $554.31( \pm 5.56)$ \\
\hline Linolelaidic (C18:2n-6t) & $676.20( \pm 5.57)$ \\
\hline linolenelaidic (C18:3n-3t) & $874.72( \pm 8.33)$ \\
\hline$\sum$ Saturatad & $21780.00( \pm 35.84)$ \\
\hline$\Sigma$ Monounsaturated & $18519.00( \pm 41.72)$ \\
\hline$\Sigma$ Polyunsaturated & $36194.00( \pm 51.04)$ \\
\hline$\Sigma$ Trans & $2105.23( \pm 6.48)$ \\
\hline Polyunsaturated/Saturated & 1.66 \\
\hline$\sum \mathrm{n}-3$ & $2789.34( \pm 19.45)$ \\
\hline$\sum n-6$ & $33405.2( \pm 66.84)$ \\
\hline Relation n-6/n-3 & 11.9:1 \\
\hline
\end{tabular}

in general and cardiovascular events. For individuals with documented cardiovascular disease, approximately $1000 \mathrm{mg}$ of $\mathrm{EPA}+\mathrm{DHA}$, preferably derived from the consumption of high fat fish, is recommended. Braised hake with interesterified margarine can supply $54 \%$ of the daily needs for healthy individuals and $27 \%$ for individuals with cardiovascular problems.

There was a significant increase $(\mathrm{p}<0.05)$ in $168 \%$ of the total saturated fatty acids in the braised fish with interesterified margarine compared to fresh samples. Likewise, in the total of monounsaturated fatty acids, the braised hake with interesterified margarine showed a significant increase $(\mathrm{p}<0.05)$ of $185 \%$ in relation to the fresh samples.

The main effect of the heat treatment was the significant increase $(\mathrm{p}<0.05)$ in the total polyunsaturated fatty acids of the braised samples with interesterified margarine (532\%), compared to fresh hake. Due to the incorporation of linoleic and linolenic fatty acids present in high concentrations in the cooking medium.
According to the nutritional information of the interesterified margarine label, $10 \mathrm{~g}$ (1 tablespoon) contains $8 \mathrm{~g}$ of lipids, $2.0 \mathrm{~g}$ of saturated fat, $2.0 \mathrm{~g}$ of monounsaturated, $3.7 \mathrm{~g}$ of polyunsaturated and $0 \mathrm{~g}$ of trans.

In relation to the ratio between polyunsaturated and saturated fatty acids, the indices were favorable in the braised. There was a significant difference $(p<0.05)$ between the braised samples compared to fresh samples. The salmon (Salmo salar L.) fresh and grilled analyzed by Tonial et al. (2010) presented 1.24 and 1.42 respectively for this ratio. The UK Department of Health and Social Security (1994) reports that the PUFA/SAFA ratio of less than 0.45 has been considered undesirable for dieting because of its potential for inducing increased blood cholesterol.

A significant difference $(\mathrm{p}<0.05)$ was observed in the $\mathrm{n} 6 / \mathrm{n} 3$ ratio between the samples braised with interesterified margarine and in natura hake. The ratios 2:1 to 4: 1 have been recommended by some authors, since it allows a greater conversion of linolenic acid to DHA, which reaches its maximum value around 2.3:1. The ingestion of $100 \mathrm{~g}$ of cooked hake with the interesterified margarine is sufficient to reach the daily recommendation for this ratio. It is important to maintain an adequate balance of omega 3 and omega 6 because inadequate balancing could accentuate a state of omega 3 deficiency. The conversion rate of a-linolenic acid in EPA and DHA is lower as the amount of linoleic acid increases, because the two substrates compete for the same enzymatic system (Novello et al., 2008).

For the sum of $n-3$, there was a significant increase of the braised hake with interesterified margarine, of $67 \%$, compared fresh hake. There was also a significant increase $(\mathrm{p}<0.05)$ of $2129 \%$ in the $n-6$ sum of the samples after cooking.

There was a significant $(p<0.05)$ increase in the content of omega 3 and omega 6 fatty acids after the cooking process, about 1.7 and 22.2 times, respectively.

On the dry basis (Table 5), it was verified that the levels of stearic, oleic, linoleic, linolenic and trans fatty acids linolelaídico of braised hake with interesterified margarine presented a significant increase $(\mathrm{p}<0.05)$, in relation to fresh hake. These fatty acids were found in high concentration in the cooking medium. Cooking resulted in an increase of $683.7 \%$ of lauric acid, relative to in natura hake. This was due to interesterified margarine having a high amount of this acid and consequently by its incorporation during cooking. The levels of docosahexaenoic and arachidonic polyunsaturated fatty acids were significantly reduced $(\mathrm{p}<0.05)$ after steaming with interesterified margarine, showing that there was destruction by oxidation or elution to the medium (Ferreira et al., 2007).

The highest amount of saturated acids, monounsaturated acids and Polyunsaturated acids on a dry basis, was found in the braised hake. Braised hake with interesterified margarine, on a dry basis, showed a fatty acid profile suitable for consumption.

\subsection{Nutritional quality indexes (NQI) of lipids}

The nutritional quality of the lipid profile evaluated by different indices is described in Table 6 . The ratio between hypocholesterolemic and hypercholesterolemic fatty acids 
Table 5. Predominant fatty acids $(\mathrm{mg} / 100 \mathrm{~g})$ of fresh white hake and braised in interesterified margarine, on a dry basis.

\begin{tabular}{|c|c|c|}
\hline FATTY ACIDS & Fresh & Braised \\
\hline \multicolumn{3}{|l|}{ SATURATED } \\
\hline Lauric (C12:0) & $53.95( \pm 9.91) \mathrm{a}$ & $422.79( \pm 65.89) \mathrm{b}$ \\
\hline Myristic (C14:0) & $180.63( \pm 56.33) \mathrm{a}$ & $246.46( \pm 13.58) \mathrm{a}$ \\
\hline Pentadecanoic (C15:0) & $61.39( \pm 9.56) \mathrm{a}$ & $26.9( \pm 2.53) \mathrm{b}$ \\
\hline Palmític (C16:0) & $1392( \pm 196.2) \mathrm{a}$ & $2019.43( \pm 99.18) \mathrm{a}$ \\
\hline Heptadecanoic (C17:0) & $66.7( \pm 12) \mathrm{a}$ & $35.21( \pm 2.99) \mathrm{a}$ \\
\hline Stearic (C18:0) & $401.33( \pm 32.59) \mathrm{a}$ & $1156.55( \pm 61.47) \mathrm{b}$ \\
\hline Arachidic (C20:0) & $16.7( \pm 12.7) \mathrm{a}$ & $49.61( \pm 5.3) \mathrm{b}$ \\
\hline Henicosanoic (C21:0) & $2.91( \pm 1.12) \mathrm{a}$ & $3.45( \pm 0.5) \mathrm{a}$ \\
\hline Behenic (C22:0) & $17.8( \pm 16.1) \mathrm{a}$ & $44.7( \pm 4.6) \mathrm{b}$ \\
\hline Tricosanoic (C23:0) & $1.9( \pm 1.7) \mathrm{a}$ & $0( \pm 0) \mathrm{a}$ \\
\hline Lignoceric (C24:0) & $4.32( \pm 3.9) \mathrm{a}$ & $16.6( \pm 2.1) \mathrm{b}$ \\
\hline \multicolumn{3}{|l|}{ MONOUNSATURATED } \\
\hline Myristoleic (C14:1n-5) & $3.5( \pm 1.9) \mathrm{a}$ & $3.69( \pm 0.83) \mathrm{a}$ \\
\hline Palmitoleic (C16:1n-7) & $493.39( \pm 64) \mathrm{a}$ & $261.49( \pm 16.6) b$ \\
\hline heptadecenoic (C17:1) & $41.28( \pm 6.12) \mathrm{a}$ & $25.4( \pm 1.23) \mathrm{a}$ \\
\hline Oleic (C18:1n-9) & $827.71( \pm 68.08) \mathrm{a}$ & $2899.71( \pm 203.91) b$ \\
\hline Cetoleic (C20:1n-11) & $107.22( \pm 21.05) \mathrm{a}$ & $96.69( \pm 6.58) \mathrm{a}$ \\
\hline Docosenoic (C22:1) & $7.45( \pm 1.56) \mathrm{a}$ & $4.7( \pm 0.07) \mathrm{a}$ \\
\hline Nervonic (C24:1) & $20.89( \pm 14.89) \mathrm{a}$ & $24.4( \pm 2.26) \mathrm{a}$ \\
\hline \multicolumn{3}{|l|}{ POLYUNSATURATED } \\
\hline Linoleic (C18:2n-6) & $69.3( \pm 14.81) \mathrm{a}$ & $4760.16( \pm 381.41) \mathrm{b}$ \\
\hline Linolenic (C18:3n-3) & $23.37( \pm 11.99) \mathrm{a}$ & $446.18( \pm 41.33) \mathrm{b}$ \\
\hline Eicosadienoic (C20:2n-6) & $17.6( \pm 14.4) \mathrm{a}$ & $8212.51( \pm 725.27) \mathrm{b}$ \\
\hline Di-homo- $\gamma$-linolenic (C20:3n-6) & $2.41( \pm 1.38) \mathrm{a}$ & $0( \pm 0) \mathrm{a}$ \\
\hline Eicosatrienoic (C20:3n-3) & $5.19( \pm 7.35) \mathrm{a}$ & $7.07( \pm 0.01) \mathrm{a}$ \\
\hline Arachidonic (C20:4n-6) & $232.14( \pm 38.56) \mathrm{a}$ & $155.47( \pm 12.00) \mathrm{b}$ \\
\hline Docosadienoic (C22:2n-6) & $2.08( \pm 1.95) \mathrm{a}$ & $0( \pm 0) \mathrm{a}$ \\
\hline Eicosapentaenoic (EPA) (C20:5n-3) & $239.47( \pm 45.12) \mathrm{a}$ & $158.65( \pm 11.73) \mathrm{ab}$ \\
\hline Docosapentaenoic (C22:5n-3) & $179.8( \pm 64.21) \mathrm{a}$ & $123.81( \pm 11.23) \mathrm{a}$ \\
\hline Docosahexaenoic (DHA) (C22:6n3) & $730.33( \pm 176.9) \mathrm{a}$ & $379.79( \pm 34.47) \mathrm{b}$ \\
\hline \multicolumn{3}{|l|}{ TRANS } \\
\hline Elaidic (C18:1n-9t) & $5.65( \pm 4.71) \mathrm{a}$ & $3.99( \pm 0.94) \mathrm{a}$ \\
\hline Linolelaidic (C18:2n-6t) & $1.9( \pm 1.7) \mathrm{a}$ & $39.61( \pm 1.57) \mathrm{b}$ \\
\hline Linolenelaidic (C18:3n-3t) & $39.02( \pm 35.03) \mathrm{a}$ & $53.95( \pm 4.41) \mathrm{a}$ \\
\hline$\sum$ Saturated & $2200( \pm 56.5) \mathrm{a}$ & $4021.82( \pm 34.78) \mathrm{b}$ \\
\hline$\sum$ Monounsaturated & $321.51( \pm 27.39) \mathrm{a}$ & $3081.07( \pm 269.99) \mathrm{b}$ \\
\hline ¿Polyunsaturated & $794.62( \pm 49.72) \mathrm{a}$ & $5302.75( \pm 107.9) \mathrm{b}$ \\
\hline$\sum$ Trans & $46.58( \pm 2.12) \mathrm{a}$ & $97.56( \pm 1.85) \mathrm{b}$ \\
\hline Polyunsaturated / Saturated & $0.36 \mathrm{a}$ & $1.32 \mathrm{~b}$ \\
\hline$\sum \mathrm{n}-3$ & $1178.18( \pm 68.87) \mathrm{a}$ & $1108.45( \pm 17.38) \mathrm{a}$ \\
\hline$\sum \mathrm{n}-6$ & $323.55( \pm 14.89) \mathrm{a}$ & $4922.71( \pm 188.78) b$ \\
\hline Relation n-6/n-3 & $1: 3.64$ & $4.44: 1$ \\
\hline $\mathrm{EPA}+\mathrm{DHA}$ & $969.8( \pm 25.85) \mathrm{a}$ & $538.45( \pm 6.69) \mathrm{b}$ \\
\hline
\end{tabular}

Mean of 10 samples analyzed in duplicate, with standard deviation between parentheses. In the same line, averages followed by the same letter do not differ from each other by the $\mathrm{F}$ test at the $5 \%$ level of significance.

Table 6. Nutritional quality indexes of the lipid fraction of fresh white hake, braised with interesterified margarine.

\begin{tabular}{cccc}
\hline White hake & $\mathrm{H} / \mathrm{H}$ & $\mathrm{AI}$ & $\mathrm{TI}$ \\
\hline Fresh & 1.31 & 0.71 & 1.36 \\
braised & 3.40 & 0.39 & 0.78 \\
\hline
\end{tabular}

$(\mathrm{H} / \mathrm{H})$ is directly related to cholesterol metabolism, and high values are desirable for this relationship (Ramos et al., 2008; Arruda et al., 2012). Menezes et al. (2008) found values inferior to the present study for mullet (Mugil cephalus) (0.41) and Camurim (Centropomus undecimalis) (0.60), both fresh. As in the salmon fillet (Salmo salar L.) (2.64) grilled (Tonial et al., 2010). There is an increase in this index after the sautéing process, due to the incorporation of the hypocholesterolemic fatty acids in relation to the hypercholesterolemic fatty acids from the cooking media used.

The atherogenicity index $(\mathrm{AI})$, relates the atherogenic acids (lauric, myristic and palmitic) and the antiatherogenic (monounsaturated and polyunsaturated n-6 and n-3 families). According to Ramos et al. (2008) low AI values are recommended. Ferreira et al. (2007) found a non-significant reduction for piranha (Pygocentrus nattereri) with thermal treatment without addition of oils (0.70) in relation to in natura (0.75). Similarly, Tonial et al. (2010) also found a non-significant reduction for salmon with heat treatment without addition of oils $(0.50)$ in relation to fresh (0.56). It is evident that both the temperature and the oils and fats used may be responsible for the change in this index. In the case of braised hake, in this study, there was an increase in antiatherogenic fatty acids from margarine, causing the atherogenicity index to be reduced. Arruda et al. (2012) reported that the lower the AI and IT values, the greater the amount of antiatherogenic fatty acids present in fats and, consequently, the greater the potential for preventing the onset of coronary diseases.

\section{Conclusions}

White hake is source of proteins and mainly lipids beneficial to health, such as polyunsaturated fatty acids n-3 (DHA, EPA, docosapentaenoic and linolenic), n-6 (arachidonic and linoleic acid), n-9 (oleic acid) and saturated (palmitic and stearic) acids. After cooking, there was a change in the centesimal composition of hake, with reduction in protein content and elevation in lipid contents. The heat treatment also caused changes in the profile of saturated fatty acids, increasing the concentration of palmitic and stearic acids. The fatty acid monounsaturated oleic showed elevation after cooking, as well as the polyunsaturated fatty acids linoleic (n-6) and linolenic (n-3). The nutritional quality indexes of the lipid fraction were favorable to consumption.

\section{References}

Ackman, R. G. (1989). Nutritional composition of fats in seafoods. Progress in Food \& Nutrition Science, 13(3-4), 161-241. PMid:2699043.

Amorim, M. M., Junqueira, R. G., \& Jokl, L. (2010). Oil and fat consumption in self-service lunch preparations. Alimentos e Nutrição, 21(2), 217-223.

Arruda, P., Pereira, E., Pimentel, P., Bomfim, M. A., Mizubuti, I. Y., Ribeiro, E. L., Fontenele, R. M., \& Regadas, J. G. L. R. Fo. (2012). Fatty acids profile of fatty acids in Longissimus dorsi of Santa Ines lambs fed different energetic levels. Asemina: Ciências Agrárias, 33(3), 1229-1240. http://dx.doi.org/10.5433/1679-0359.2012v33n3p1229.

Association of Official Analytical Chemists - AOAC. (1990). Official methods of analysis of AOAC International. Arlington: AOAC. 
Barbalho, S. M., Bechara, M. D., Quesada, K. R., \& Goulart, R. A. (2011). Role of omega-3 fatty acids in the resolution of inflammatory processes. Medicine (Ribeirão Preto), 44(3), 234-240. http://dx.doi. org/10.11606/issn.2176-7262.v44i3p234-240.

Department of Health and Social Security. (1994). Nutritional aspects and cardiovascular disease: report on health and social subjects. Report of the Cardiovascular Review Group Committee on Medical Aspects of Food Policy, 46, 1-186. PMID: 7863112.

Domínguez, Y. L. (2008). Diet in Alzheimer's disease. Revista Cubana de Salud Pública, 35(4), 55-64.

Ferreira, M. W., Bressan, M. C., Souza, X. R., Vieira, J. O., Faria, P. B., \& Andrade, P. L. (2007). Effect of cooking methods on the chemical composition and lipid profile of Nile tilapia fillets (Oreochromis niloticus Linnaeus 1757). Ciência e Agrotecnologia, 31(3), 798-803. http://dx.doi.org/10.1590/S1413-70542007000300029.

Folch, J., Lees, M., Stanley, G. H. S. J. (1957). A simple method for the isolation and purification of total lipides from animal tissues. The Journal of Biological Chemistry, 226(1), 497-509. PMID: 13428781.

Gladyshev, M. I., Sushchik, N. N., Gubanenko, G. A., Demirchieva, S. M., \& Kalachova, G. S. (2007). Effect of boiling and frying on the content of essential polyunsaturated fatty acids in muscle tissue of four fish species. Food Chemistry, 101(4), 1694-1700. http://dx.doi. org/10.1016/j.foodchem.2006.04.029.

Guiné, R. F., \& Henriques, F. (2011). The role of fatty acids in human nutrition and developments in how they influence health. Millenium, 40, 7-21.

Hartman, L., \& Lago, R. (1973). Rapid preparation of fatty acid methyl esters from lipids. Laboratory Practice, 22, 475-476.

Menezes, M. E. S., Lira, G. M., Omena, C. M. B. O., Freitas, J. D., \& Sant'ana, A. E. G. (2008). Nutritional value of fish off the coast of Alagoas, Brazil. Revista do Instituto Adolfo Lutz, 68(1), 21-28.

Micha, R., \& Mozaffarian, D. (2010). Saturated fat and cardiometabolic risk factors, coronary heart disease, stroke, and diabetes: a fresh look at the evidence. Lipids, 45(10), 893-905. http://dx.doi.org/10.1007/ s11745-010-3393-4. PMid:20354806.

Neeharika, T. S., Rallabandi, R., Ragini, Y., Kaki, S. S., Rani, K. N., \& Prasad, R. B. (2015). Lipase catalyzed interesterification of rice bran oil with hydrogenated cottonseed oil to produce trans free fat. Journal of Food Science and Technology, 52(8), 4905-4914. http:// dx.doi.org/10.1007/s13197-014-1563-8. PMid:26243910.

Novello, D., Franceschini, P., \& Quintiliano, D. A. (2008). The importance of $\omega-3$ and $\omega-6$ fatty acids for disease prevention and human health. Salus Magazine., 2(1), 77-87.
Oliveira, J. M., Luzia, L. A., \& Rondó, P. H. C. (2012). Fatty acids poliunsaturated omega-3: cardiovascular health and environmental sustainability. Food and Nutrition Security, 19(1), 89-96.

Oliveira, V., Roberto, N., Lino, L. H., Bezerra, R., \& Porto, A. (2014). Partial characterization of the metal ions of a protease with collagenolytic properties extracted from digestive viscera of white hake (cynoscion leiarchus). Health and Science Journal. Online (Bergheim), 3(3), 266-272.

Piñeiro-Corrales, G., Rivero, N. L., \& Culebras-Fernández, J. M. (2013). Role of omega-3 fatty acids in the prevention of cardiovascular diseases. Nutrición Hospitalaria, 28(1), 1-5. PMid:23808424.

Ramos, M. M. Fo., Ramos, M. I. L., Hiane, P. A., \& Souza, E. M. T. (2008). Lipid profile of four fish species from the Mato Grosso do Sul wetland region. Food Science and Technology, 28(2), 361-365.

Rosa, F., Bressan, M. C., Bertechini, A. G., Fassani, E. J., Vieira, J. O., Faria, P. B., \& Savian, T. V. (2006). Effect of cooking methods on the chemical composition and cholesterol in the breast and thigh of broilers. Ciência e Agrotecnologia, 30(4), 707-714. http://dx.doi. org/10.1590/S1413-70542006000400017.

Santos, L. E. S., \& Bortolozo, E. A. F. Q. (2008). Ômega 3 intake: considerations about potential benefits in lipid metabolism. Agricultural Science and Engineering, 14(2), 161-170.

Santos, R. D., Gagliardi, A. C. M., Xavier, H. Z., Casella, F. A., Araújo, D. B., Cesena, F. Y., Alves, R. J., Pereira, A. C., Lottemberg, A. M. P., Chacra, A. P. M., Faludi, A. A., Sposito, A. C., Ribeiro, F. F. F., Fonseca, F. A. H., Giuliano, I. C. B., Catani, L. H., Bertolami, M. C., Miname, M. H., Izar, M. C. O., Monte, O., Maranhão, R. C., Martinez, T. L. R., Machado, V. A., Rocha, V. Z., \& Salgado, F. W. I. (2012). Brazilian guideline for Family Hypercholesterolemia (HF). Arquivos Brasileiros de Cardiologia, 99(2, Suppl. 2), 1-28.

Santos-Silva, J., Bessa, R. J. B., \& Santos-Silva, F. (2002). Effect of genotype, feeding system and slaughter weight on the quality of light lambs: II. Fatty acid composition of meat. Livestock Production Science, 77(2-3), 187-194. http://dx.doi.org/10.1016/S0301-6226(02)00059-3.

Sucupira, N. R., Xerez, A. C. P., \& Souza, P. H. M. (2012). Vitamin losses during food thermic treatment. Science Biology Health, 14(2), 121-128.

Tonial, L. I. B., Oliveira, D. F., Bravo, C. E., Souza, N. E., Matsushuta, M., \& Visentainer, J. V. (2010). Physico-chemical characterization and lipid profile of salmon (salmo salar L.). Alimentos e Nutrição, 21(1), 93-98.

Ulbricht, T., \& Southgate, D. (1991). Coronary heart disease: seven dietary factors. Lancet. 338, 985-992.

Watt, B., \& Merrill, A. L. (1963). Composition of foods: raw, processed, prepared (Agriculture Handbook, No. 8). Maryland: Agricultural Research Service. 